\title{
Armed conflict and fisheries in the Lake Victoria basin
}

\author{
$\underline{\text { Sarah M. Glaser }}^{1,2}$, Cullen S. Hendrix ${ }^{2,3}$, Brittany Franck $^{4}$, Karin Wedig $^{5}$ and Les Kaufman $^{6,7}$
}

\begin{abstract}
Civil conflict is the most prevalent form of armed conflict in the world today, but this significant driver of food and income security has been largely missing from studies of fisheries. Fisheries conflict is an example of complex dynamics operating in social-ecological systems. We theorize and document the existence of such a feedback loop between conflict in Uganda and fisheries in Lake Victoria. Civil war in northern Uganda resulted in mass human population displacement, which corresponded in time with increases in fishing effort in Lake Victoria. Subsequent changes in catch of Nile perch, the dominant commercial fishery, sparked armed conflict in the lake itself, at Migingo Island, between Uganda and Kenya. From this case study, we draw seven main conclusions. First, these correlation-based relationships are illustrative but not conclusive and we call for further empirical investigation. Second, the couplings between conflict and fishing subsystems are spatially asymmetric: conflict effects are diffuse in their links to broad changes in the fishery, whereas fishery effects may produce more localized conflict events. Third, and most relevant to conflict scholars, the drivers of fishing effort and catch may originate in different subsystems, but their changes and effects must be analyzed in concert. Fourth, the complex and path-dependent impacts of conflicts on natural resources in general, and fisheries in particular, highlights the urgent need for targeted surveys and more mechanistic understanding. Fifth, the open access nature of fisheries in Lake Victoria may exacerbate instabilities not present in other systems. Sixth, the diffuse and context-specific effects of conflicts on fisheries means models of fisheries management (e.g., stock assessment) should not incorporate conflict as a driver at this time. Finally, countries and their stakeholders should focus on diversification in employment for short term coping mechanisms during conflict as a means of shortcircuiting the conflict-fisheries feedback loop.
\end{abstract}

Key Words: fisheries conflict; food security; internally displaced persons; Lake Victoria; social-ecological systems

\section{INTRODUCTION}

Declining fish stocks coupled with increasing global demand for fisheries products are contributing to a growing risk of fisheries conflict (Pomeroy et al. 2016). Given strong links between fisheries and food security, McClanahan et al. (2015) predicted conflict over fisheries will grow as a north-south imbalance in access to fisheries products widens. A sizeable majority of fisher folk live in developing countries where fisheries contribute critically to food security and, by extension, to social stability (Muawanah et al. 2012, Hendrix and Brinkman 2013, FAO et al. 2017). Existing typologies of fisheries conflict (e.g., Charles 1992, Warner 2000 as cited in Bennett et al. 2001) provide comprehensive frameworks to categorize and understand the causes of conflict within fisheries systems. However, they are mostly limited to understanding conflict within and over fisheries resources, and not the role of fisheries within a larger conflict system whereby conflict may originate outside the fishery. Moreover, although existing typologies can accommodate violent armed conflict, they are more appropriate for describing low-level, nonviolent conflicts such as those between resource user groups.

This study aims to improve our understanding of fisheries conflict by expanding the lens to violent armed conflict beyond the fishery system in the Lake Victoria basin. Lake Victoria is one of the most dynamic social-ecological systems on Earth (Downing et al. 2014). The Lake Victoria basin (Fig. 1) is one of the most densely populated regions in Africa. Between 2000 and 2010, the basin population grew from $\sim 54.5$ million to $\sim 73.6$ million. Population growth along the lakeshore nearly doubled $(\sim 3.1$ million to $\sim 5.8$ million) over the same period (authors' calculations from CIESIN-CIAT 2005 and Linard et al. 2012). Undernourishment is prevalent, ranging from $19.1 \%$ of total population in Kenya to $58 \%$ in Burundi (FAO et al. 2017, WFP 2017).

Since 1989, the Lake Victoria basin has been one of the most conflict-affected regions in the world (Sundberg and Melander 2013; Fig. 1), with major civil conflicts having occurred in Burundi, the Democratic Republic of the Congo, Rwanda, and Uganda. Lake Victoria basin countries accounted for $20 \%$ of the continent's population but $40 \%$ of the battle deaths that occurred continent-wide (Sundberg and Melander 2013). These conflicts caused widespread population displacement and impeded both economic and human development.

Our interest in possible links between armed conflict in Uganda and fisheries in Lake Victoria was generated by an observation: the number of internally displaced persons (IDPs), i.e., forced to flee their homes but who remained inside their country's borders, created by civil war in northern Uganda is strongly correlated to reported Nile perch (Lates niloticus) catch by Ugandan fishers between 1997 and 2010 (Fig. 2). Bivariate correlations between IDPs (contemporaneous and lagged) and Nile perch catch are 0.75 and 0.89 , respectively $(\mathrm{p}<0.05)$.

Quantifying a direct relationship between civil armed conflict and fisheries is likely to be challenging because causal links between environmental change (more generally) and conflict are neither "tight [n]or deterministic" (Homer-Dixon 1991). However, these correlations are sufficiently strong to be intriguing, and we suggest

\footnotetext{
${ }^{1}$ Secure Fisheries program, One Earth Future, ${ }^{2}$ Korbel School of International Studies, University of Denver, ${ }^{3}$ Peterson Institute for International Economics, ${ }^{4}$ Department of Anthropology, University of Arizona, ${ }^{5}$ Africa Chief Economist, Deutsche Gesellschaft für Internationale Zusammenarbeit (German Society for International Cooperation, GIZ), ${ }^{6}$ Department of Biology \& Pardee Center for the Study of the LongerRange Future, Boston University, ${ }^{7}$ Conservation International
} 
a possible mechanism: armed conflicts that occur away from fishing grounds may increase fish catch as a result of displaced population and greater fishing effort. We thus propose that civil conflict in Uganda interacts with the fisheries in Lake Victoria through the mechanisms of population displacement, fishing effort, and fish catch.

Fig. 1. The Lake Victoria basin countries include Uganda, Kenya, Tanzania, Rwanda, and Burundi. Armed conflict events have occurred throughout the basin. Data points represent estimated deaths from individual battles or changes of territory in an armed conflict between one of the national governments of the respective countries and an armed, organized insurgent group (1997-2010). Data are from the Uppsala Conflict Data Project's Georeferenced Event Dataset (Sundberg and Melander 2013).

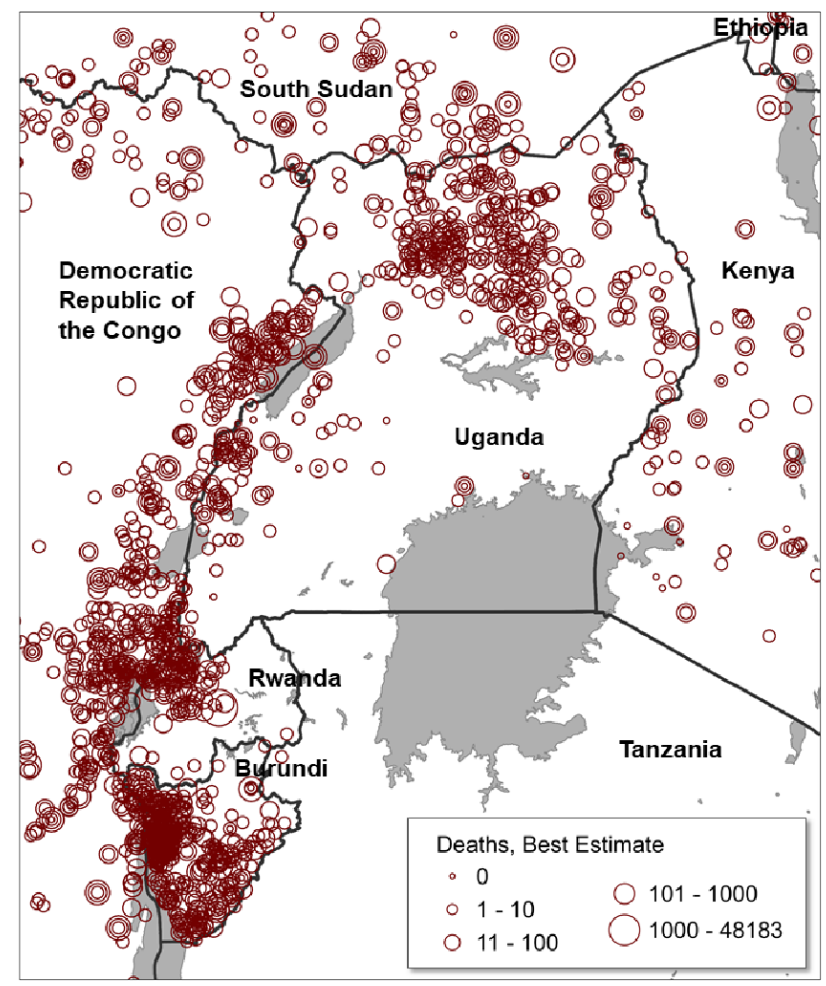

\section{INTEGRATING ARMED CONFLICT INTO FISHERIES DYNAMICS}

Pomeroy et al. (2016) issued an ambitious and comprehensive conceptual model of the primary drivers and conditions mediating "fish war cycles." They suggested fisheries scarcity, competition over fisheries resources, and conflict are linked in a feedback loop driven by dozens of related factors such as religious conflict, land-based pollution, and competition for space. In their model, armed conflict affects the fish war cycle by influencing the overall level of conflict in society. This stems from some of their earlier findings that communities with higher baselines of conflict, generally, were more likely to experience fisheries conflict, specifically (Pomeroy et al. 2007).
Fig. 2. The numbers of internally displaced persons (IDPs) in Uganda, largely resulting from the conflict in northern Uganda with the Lord's Resistance Army, is strongly correlated with catch of Nile perch by Ugandan fishers (contemporaneous $\mathrm{r}=$ 0.75 ; one-year lag $r=0.89$; both $p<0.05$ ). This observation is in line with our theoretical priors and has guided our case study. Catch data are from FAO Fishstat (2015). The IDP data are from the Norwegian Refugee Council and Internal Displacement Monitoring Centre (2012). Data from 1998 are interpolated from 1997-1999.

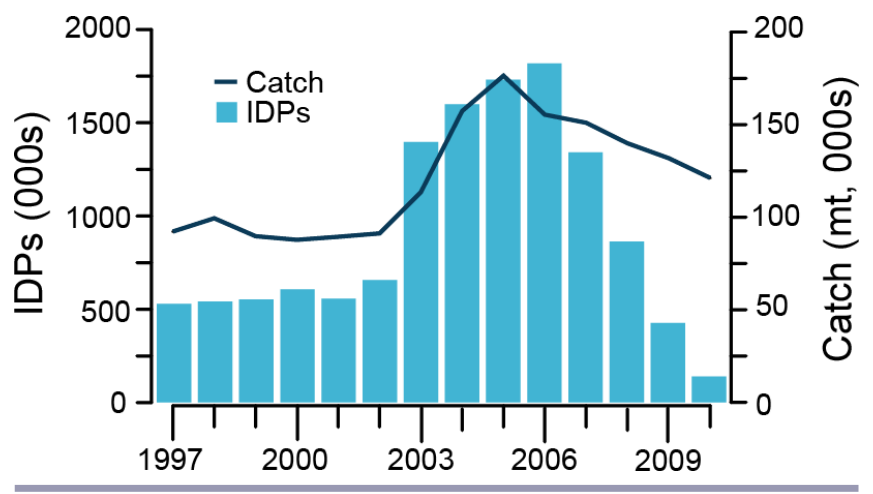

Armed conflict can have a direct impact on fisheries. Hendrix and Glaser (2011) demonstrated that civil conflict depressed reported fish catch. In 123 countries over 50 years, the outbreak of civil war corresponded to an average $16 \%$ decline in fish catch reported by the country in conflict to the United Nations Food and Agriculture Organization (FAO). Conversely, Mitchell and Thies (2012) found armed conflict was associated with an increase in fish catch. More recent estimates by Belhabib et al. (2018) leverage reconstructed artisanal, subsistence, and industrial catch time series to estimate the effect of a variety of extreme events (such as wars or hurricanes) on fisheries, finding an aggregate increase in fish catch in response to these events. However, their analysis also points to differential effects of armed conflict in different settings, with catches rising in some cases but falling in others. It remains to be seen under what conditions conflict may lead either to a decline or a rise in fish catch, but the location of armed conflict, and physical proximity to the fishery, is a likely explanation.

Figure 3 diagrams our proposed framework defining armed conflict-based human subsystems and fishery-based natural subsystems coupled by fishing effort and fish catch. In the human subsystem, armed conflict, livelihoods, and food security are linked through employment and food prices. As food and livelihood insecurity increase, armed groups may find more willing recruits and social unrest may increase (Fjelde 2015). However, these relationships are contingent upon political, economic, and social context (Hendrix and Brinkman 2013). Armed conflict often results in widespread human population displacement, exacerbating unemployment and food insecurity through migration and market disruptions (Gates et al. 2012). This subsystem determines food prices, demand for food, and access to food resources, and these variables shape the process of fishing effort. Changes in demand for food, prices of food, and 
Fig. 3. Our conceptual conflict-fisher system is comprised of couplings between the human subsystem containing conflict and a natural aquatic subsystem containing fish populations. Fishing effort and fish catch play critical roles: both variables independently assimilate the influences of multiple variables originating within their respective subsystems while linking one subsystem to the other.

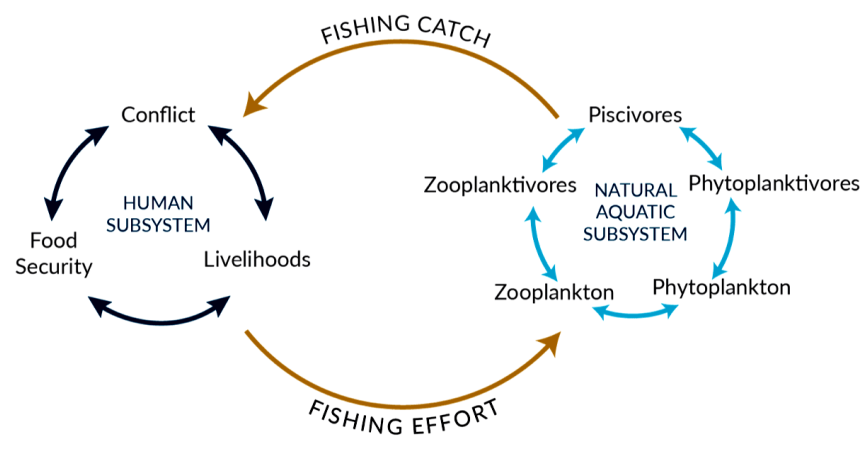

labor availability lead to changes in incentives to put effort into fishing.

Within the food web of the natural subsystem (Fig. 3), piscivores consume midtrophic zooplanktivores and phytoplanktivores, which are linked to each other indirectly though predation on zooplankton and phytoplankton. The resulting dynamics of fish population abundance depend on food web structure, primary productivity, and patterns of species diversity (for Lake Victoria examples, see Achieng 1990 and Downing et al. 2012). Finally, fish abundance is one major determinant of total fish catch: if effort is constant, when fish abundance increases, catch should increase.

In our conflict-fishery system, effort and catch play unique roles as variables that are derived from processes within each subsystem and couple the subsystems together. As a coupled system, then, armed conflict in the human subsystem helps determine fishing effort, fishing effort affects fish abundance, constraints imposed by the natural subsystem determine catch, and catch affects income and food security and thus the likelihood of armed conflict, though its effects may manifest at different scales.

\section{THEORETICAL FRAMEWORK}

\section{The human subsystem: armed conflict, livelihoods, and food security}

Our expectations for the impacts of armed conflict on fisheries are grounded in empirical understanding of the environment and security in general. There is now a large, multidisciplinary literature on the relationships between natural resources and political violence. These studies demonstrate that violent conflict and natural resources exhibit reciprocal, dynamic feedbacks. Conflict dynamics include whether or not armed conflict occurs (Homer-Dixon 2001, Fearon 2005, Humphreys 2005, Fjelde 2015), the aims of conflict (Le Billon 2001, 2012, Sorens 2011), conflict duration (Fearon 2004, 2005, Ross 2004, Lujala 2010), conflict intensity (Lujala 2009), and whether conflict actors engage in widespread human rights abuses against civilians
(Humphreys and Weinstein 2006). These dynamics are strongly influenced by the availability of different types of natural resources (Fig. 3). Additionally, properties of the underlying resources, including rates of extraction/exploitation(Mitchell and Thies 2012) and reproduction (Dudley et al. 2002, Daskin and Pringle 2018), and efforts at comanagement of endangered species (Martin et al. 2011) can all be influenced by the presence or absence of armed conflict.

Although studies have documented the effects of large-scale international wars on fisheries, the literature on the effects of civil conflict on fisheries is much smaller (Jacquet et al. 2010, Hendrix and Glaser 2011, Mitchell and Thies 2012). Maritime interstate wars, notably World Wars I and II, had short-term positive effects on fish abundance by providing wartime refugia, i.e., regions in which civilian activity was limited because of military activity, in areas of heavy naval activity (Jennings et al. 2001). This mechanism is usually absent in civil conflicts because the vast majority of civil conflicts are not maritime affairs. Murphy's (2007) study of maritime insurgency identified only four groups that engaged in maritime attacks with any regularity: the Liberation Tigers of Tamil Eelam (Sri Lanka), Gerakan Aceh Merdeka (Indonesia), Abu Sayyaf Group (Philippines), and AlQaeda (the USS Cole and the MV Limberg attacks, both of which took place in Yemen). Instead, civil conflicts may affect fisheries through changes in fishing effort that arise either through movement of people or changes in market demand driven by curtailed access to other kinds of food.

Armed conflicts have more general effects for food and livelihood security by affecting the ability to produce, trade, and access food (United Nations 1993). In 13 of 18 conflict-affected countries surveyed by Stewart et al. (2001), food production declined. Children in Burundi, Rwanda, and Zimbabwe who lived through armed conflict were stunted at disproportionate rates, affecting their health, education, and economic opportunities later in life (Alderman et al. 2006, Blattman and Miguel 2010). A macrolevel analysis indicates medium-sized conflict, with 2500 battle deaths, increased undernourishment in the population by an additional 3.3\% (Gates et al. 2012). Armed conflict also affects food and livelihood security by destroying critical infrastructure. Destruction of bridges, roads, and power grids impairs the production and distribution of food, medical supplies, and clean water, resulting in increased mortality (Ghobarah et al. 2004).

Finally, armed conflict affects food and livelihood security by spurring migration, both internally and across borders. Civil conflicts tend to result in disproportionately high civilian casualties, creating strong incentives for out-migration from affected areas. The flight to safety entails the loss of property, livelihood, and community. Refugees often find themselves inhabiting marginal lands with few economic prospects, making them more dependent on humanitarian assistance (Salehyan and Gleditsch 2006). This is one of the most powerful mechanisms by which civil conflicts result in significant macroeconomic contractions (Cerra and Saxena 2008). Ultimately, these changes in the dynamics within the human subsystem interact to affect fishing effort.

The effects of armed conflict on fisheries subsystems, as mediated through fishing effort (Fig. 3), are likely to exhibit explicit spatial and scaling effects. Civil conflict that takes place near fishing 
communities may affect fishing effort through at least four processes: redeployment of labor, population displacement, counter-insurgency strategy and tactics, and third-party encroachment into national fishing grounds (Hendrix and Glaser 2011). First, as civil conflicts develop, people may leave fisheries and join insurgent movements for economic, political, or ethical reasons. Second, as people are displaced from their homes for reasons other than joining militias, fishing effort in the region should decline given fewer people living in the region. Third, direct military actions (e.g., port blockades) may reduce access to fishing grounds: Israel's blockade of Lebanon in the 1970s caused that country's fishing industry to collapse (Hendrix and Glaser 2011). Finally, if governments are expending resources fighting insurgencies, resources for enforcing territorial boundaries and monitoring, control, and surveillance decline, presenting greater opportunity for illegal and unreported fishing, including by other countries. The first three mechanisms should cause fishing effort to decline. The fourth mechanism, however, may appear to cause a decline but may in fact cause a net increase in effort if illegal fishing is attracted to areas of poor monitoring. This mechanism is explored by Jacquet et al. (2010), who found fish landings for Mozambique during that country's civil war (1977-1992) were significantly underreported.

On the other hand, armed conflict in neighboring countries and areas distant from fishing may increase demand for fish in local or regional markets and therefore increase fishing effort through two primary mechanisms. First, displacement from conflictaffected regions may increase human populations in areas of fishing, leading to increased effort. This mechanism is explored in detail in our case study. Second, conflict in neighboring countries and more distant territories may depress food production there, making those areas more dependent on food sourced from more distant markets. This mechanism is not explored in detail in our case study of Uganda, but some anecdotal evidence exists. Conflicts in neighboring countries, particularly the Democratic Republic of Congo, drove up demand for dried dagaa (Rastrineobola argentea) from Lake Victoria, which is an ideal "fast food" source of protein, i.e., it does not spoil and is lightweight relative to its nutritional content, for people who were either fleeing conflict zones or were directly involved in fighting (W. W. Mwanja, personal communication). This mechanism is observed in virtually all conflict zones and is not unique to fish.

\section{The natural subsystem: trophic dynamics of fish populations}

Complicated food web interactions mean different fish species may respond differently to the same change in fishing effort. Even if fishing effort in a multispecies fishery increases evenly across species, not all populations may decline. Classically, we would expect targeted populations to decline under increasing fishing pressure. However, given food web interactions that promote functional redundancy, competitive release, and predator switching, some fish populations may increase in response to generalized fishing effort (Kondoh 2003). As effort increases, a fish population may respond by reproducing more rapidly (and therefore maintaining numbers in the face of greater mortality) or fish populations may decline, depending upon the life history characteristics of the species in question (Cushing 1974, Jennings et al. 1998). In the former case, the observed catch per unit effort (CPUE) should remain constant whereas in the latter case, the observed CPUE should decline. Thus, the nature of the feedback between fish populations and the economic drivers of fishing effort are dependent on the conditions (abundance) of the target fish population. Likewise, predictions about the direction of population response to the driver of fishing effort should be made at the scale of targeted species and with some understanding of potential biological mechanisms.

Changes in fish abundance necessarily cause changes in catch from that system. In the early stages of a fishery, catch increases as the number of fishers increase and as technology and knowledge about the fishery improve, but the increasing catch does not reflect an increasing fish population. When the fishery is established but still relatively young, annual variability in catch should reflect variability in the underlying population: in higher abundance years, catch goes up, and in lower abundance years, catch goes down (Pauly et al. 2013). In an older and technologically mature fishery, populations decline but CPUE may remain oddly stable until most population refugia have been exhausted, at which point both CPUE and total catch will plummet (Harley et al. 2001). This is why effort and catch are ideally analyzed in concert. However, the mechanisms that drive effort and those that drive catch are different yet linked through biological and economic processes. For example, in a case study of Mozambique and Tanzania, Jacquet et al. (2010) found that CPUE in Mozambican fisheries declined as concentrated fishing effort increased because of immigration to fisheries of persons displaced by conflict.

To close our conceptual loop in Figure 3, fish catch affects the human system through socioeconomic considerations such as wages and food prices, and ultimately, well-being (McClanahan et al. 2015). As catch increases, the effect on society depends on how the benefits of greater catch are distributed. These effects may operate through a variety of mechanisms. For example, decline in the capture fishery could lead to increased unemployment among young men in a region already characterized by high unemployment and idling, two factors associated with individual proclivity to participate in rebel groups and street gangs (World Bank 2011). Alternately, declining catch could lead to higher food prices, the social stability effects of which are ambiguous. Higher prices may help fisher and fishery-linked households, but lead to discontent on the part of consumers, for whom higher prices constitute a loss of welfare. Higher food prices have also been linked to social unrest (Smith 2014, Bellemare 2015, Hendrix and Haggard 2015).

If fish are too abundant in the marketplace and prices decline, the effect may be negative from the point of view of the fishers but positive from the point of view of consumers. If, on the other hand, prices remain stable, fishing will provide a reliable form of income to those in its employ. Or, if catch declines and prices rise, fishers could face a boon in the form of higher income, but society as a whole may face greater food insecurity. Thus, fish catch would make conflict more or less likely depending on the economic and social conditions present (Pomeroy et al. 2016). Furthermore, changes in catch could contribute to conflicts between adjacent fishing communities over access to fishing grounds or between governments should those fishing grounds be transboundary in nature (Hendrix and Glaser 2011). In the latter case, conflicts between fishers who are citizens of different countries may expand 
as each petition their government to intercede on their behalf (Mitchell and Prins 1999). The realization of these effects emerges from complex interactions of a host of factors and forms the basis of our case study.

\section{THE FISHERIES OF LAKE VICTORIA AND ARMED CONFLICT IN UGANDA}

\section{Background}

Conflict between the Ugandan government and the Lord's Resistance Army (LRA) began in the mid-1980s. It emerged in the context of an earlier conflict between the remnants of the recently ousted military junta, then called the Uganda People's Defence Army (UPDA), composed largely of ethnic Acholis, and the newly established National Resistance Army (NRA) government, led by Yoweri Museveni, Uganda's current president. Centered in the northern Ugandan districts of Gulu, Kitgum, and Pader, the fighting involved large-scale attacks against Acholi communities. Around the same time, an Acholi woman named Alice Auma began raising another rebel force in Acholiland, purportedly while possessed by a Christian spirit. Her Holy Spirit Movement (HSM) grew rapidly and enjoyed some successes in battles with government forces. Their march southward, to the capital Kampala, ultimately bogged down outside of Acholiland, where the HSM had enjoyed the sympathies of the local population. The HSM was defeated in Iganga in late 1986 (UCDP 2014).

Early in 1987, Joseph Kony's LRA began attacking government forces. As with the UPDA and HSM before it, ethnic Acholis dominated the LRA. Unlike these groups, however, the LRA was able to secure external support from the Sudanese government, in the form of safe havens and arms, beginning in the 1990s. Throughout the 1980s and 1990s, the governments of Sudan and Uganda engaged in a proxy war, avoiding direct military engagement but each providing support for a rebel organization in the other's territory (the SPLA/M in Sudan, the LRA in Uganda). This dynamic, i.e., the delegation of war to rebel organizations to avoid direct engagement, is common in civil conflicts (Salehyan 2010). Freed from dependence on the local Acholi population for material support, but not for person power, the LRA became increasingly abusive of civilians, resorting to large-scale kidnapping of children to staff its army and provide logistical support (Wood 2010).

These conflicts coincided with major changes to the fisheries in Lake Victoria. Fishing is a major source of employment in the immediate vicinity of Lake Victoria. In 2016, 219,919 fishers worked the lake (LVFO 2016). If each fisher generates four additional secondary (fish drying, processing) or ancillary (boat building, gasoline sales) jobs (World Bank 2013, Teh and Sumaila 2013), the sector employs approximately $1,026,000$ people, roughly one-third of the working-age population in the immediate lake vicinity.

The introduction of nonnative fishes has had an impact on the Lake Victoria food web. In the late 1950s, Nile perch and several species of tilapia (primarily Oreochromis niloticus) were introduced to the lake basin in the wake of severe overfishing of indigenous tilapiines and cyprinids. The introduced species supported a growing regional fishery: by the 1980s, perch and nonnative tilapia populations dominated the lake ecosystem
(Ogutu-Ohwayo 1990, LVFO 2015) along with a small endemic pelagic cyprinid, Rastrineobola argentea (known as dagaa in Kiswahili). This three-species fishery generates income for fishers and a product for a large export market to Europe, the Middle East, North Africa, and North America (Geheb et al. 2008). However, the growth of these species came at the expense of lake biodiversity because of a complex mix of direct and indirect effects (Ogutu-Ohwayo 1990, Kaufman 1992, Kitchell et al. 1997, Balirwa et al. 2003, Downing et al. 2014, van Zwieten et al. 2016).

Although the dagaa fishery has exploded recently, there have been concurrent indications that the Nile perch fishery has fluctuated in the face of fishing pressure. In 2011, lake-wide catch for Lake Victoria Nile perch was down $36 \%$ from its peak in 2008; however, catch rebounded $26 \%$ by 2014 and recent surveys of the lake show the population may be stabilizing (LVFO 2015). This decline in catch during the late 2000s coincided with a large increase in fishing effort. In 2000, surveys by the Lake Victoria Fisheries Organization (LVFO) estimated 129,305 active fishers on the lake. By 2012, that number had increased to over 205,000, an increase of $59 \%$.

Lake-wide, there has been a concurrent slight decline $(100 \mathrm{~kg}$ per year) in CPUE measured as $\mathrm{kg}$ of fish fisher ${ }^{-1}$ year ${ }^{-1}$. The sustainability of the fishery is now questionable. Although there is debate about whether the fishery has collapsed or not (Kolding 2013), the fact that greater effort must be expended is not good news for fishers and may portend declining income and fewer employment opportunities in the fishery. Most formal statistics measure the income generation from Nile perch through the profitable export industry, however the capture of immature Nile perch is an important (but unmeasured) contribution directly to food security. The illegal capture of Nile perch below $50 \mathrm{~cm}$ total length is understood to be a biological threat to the Nile perch population, but it also is an important source of income for local villagers, especially women.

\section{Proposed mechanisms: linking armed conflict and fisheries in the Lake Victoria basin}

Figure 4 elucidates our proposed mechanistic relationships (and the directional relationship thereof) between key variables. Civil conflict in northern Uganda contributed to population displacement as Ugandans fled violence: as conflict worsened, population displacement increased. This displacement affected fishing effort both directly, as some displaced persons sought to join the fishery for new employment, and indirectly through general effects on job markets in less-affected areas. As human population displacement increased, fishing effort increased. Initially, higher fishing effort translated into higher catches of Nile perch. Over time, however, persistent high fishing mortality resulted in a decline in Nile perch abundance throughout the lake, resulting in increased competition for dwindling stocks. This resulted in increasing tensions at Migingo Island, a Nile perch fish landing site claimed by both Kenya and Uganda. We now turn to exploring these links in greater detail.

Link 1: civil conflict drove internal population displacement As the civil war in northern Uganda intensified and battle deaths increased, the number of internally displaced persons also increased (Pearson correlation, $\mathrm{p}<0.05$ ), consistent with Link 1 (Fig. 5). Persistent fighting and LRA raids on northern communities had two major impacts: large-scale population 
Fig. 4. Possible links coupling armed civil conflict in Uganda to Lake Victoria fisheries. The sign represents the hypothesized direction of the bivariate relationship (i.e., the sign on the correlation coefficient) as detailed in the text and following figures.

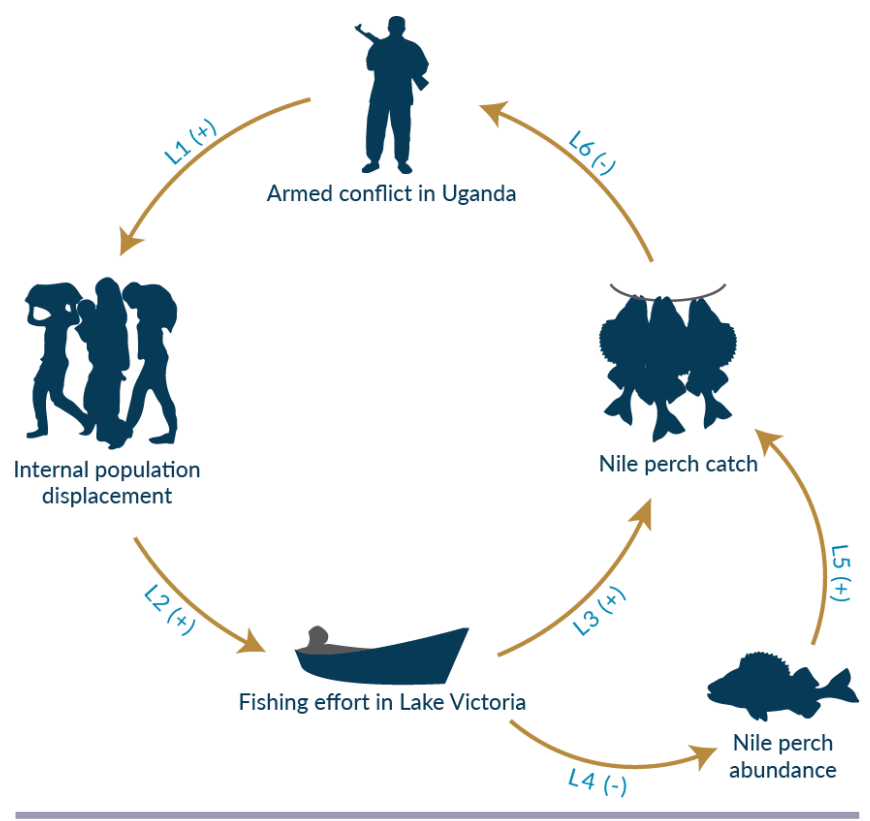

Fig. 5. Increasing conflict intensity, measured by conflictrelated deaths, is correlated with greater internal population displacement (IDP). Battle death data are from the Uppsala Conflict Data Program (UCDP 2015). The IDP data are from the Norwegian Refugee Council and Internal Displacement Monitoring Centre (2012). Lagged (one-year) battle deaths and contemporaneous IDP populations are correlated at $\mathrm{r}=0.62, \mathrm{p}$ $<0.05$.

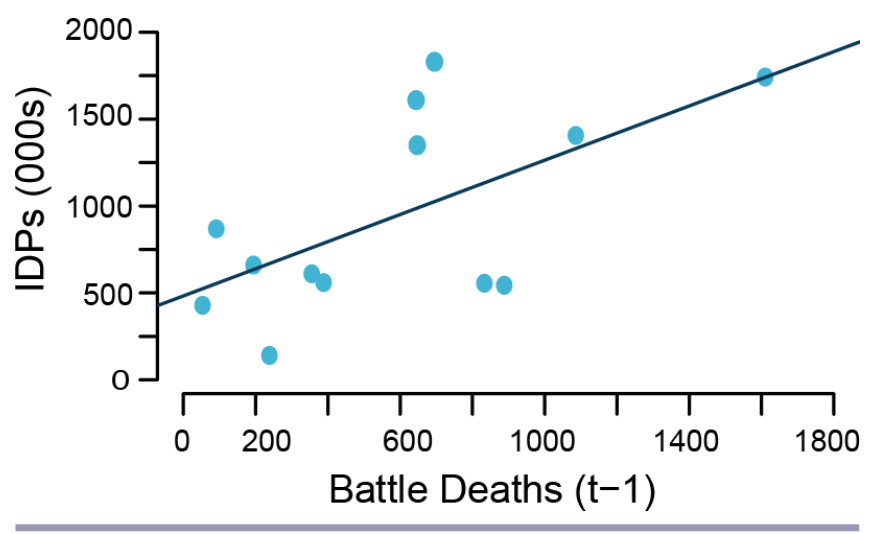

displacement and creation of food shortages due to abandonment of agricultural production in search of safety.Displaced persons remained in Uganda, both due to the unattractiveness of fleeing across borders (neighboring regions in the DRC and southern Sudan were active war zones) and government policy. In 1996, the Ugandan government instituted a policy of forced displacement to "protected villages:" IDP camps in which the government could ostensibly provide greater protection from LRA attacks. In 1997, there were 532,000 Ugandans living in IDP camps. By 2005-2006, those ranks had swelled to almost two million (NRC and IDMC 2012; Fig. 2).

Internal displacement caused food production in affected regions to decline drastically (Fig. 4). The Acholiland region accounts for over $20 \%$ of Uganda's arable land, and before the conflict it was the source of surplus production of food crop and cotton, as well as significant livestock holdings (FAO 2009). The conflict curtailed agricultural production and led to livestock loss, which imposed a double burden because the animals were no longer available to pull plows. According to the Ugandan National Household Survey for $2005 / 06$, over $85 \%$ of the population was considered food insecure in the Acholi subregion, the most conflict-affected area (Office of Disaster Management 2012). The IDP population became almost entirely dependent on emergency food assistance and food sourced from more distant regional markets (Pingali et al. 2005, Mulumba and Olema 2009).

Although these IDP numbers are large, they undercount the true number of displaced persons substantially. Official IDP statistics only count those who were relocated to protected villages and received emergency assistance (Mulumba and Olema 2009). This accounting does not capture those living with host families, friends, or relatives, in urban settings, in transit between locations, and those whose internal migration may have been motivated in part by conflict or coercion but that is not self-recognized as displacement (NRC et al. 2008). Anecdotally, the authors have interacted with several individuals (ranging from students to government employees) whose families relocated to southern Uganda (Kampala and Jinja, primarily) during the height of the conflict, but who never transited through a camp or at any point self-identified as displaced persons. These self-settled refugees are notoriously difficult to count, though an estimate published in 2005 , when roughly 1.8 million persons were in official IDP camps, suggested there were anywhere from 300,000-600,000 additional self-settled IDPs in the towns of Gulu, Lira, and Kampala alone (Grace 2005; Fig. 2). Thus, 300,000 is a very conservative, lowerbound estimate of the true number of self-settled IDPs. Moreover, these self-settled IDPs were disproportionately likely to be young men: according to UNHCR estimates, $80 \%$ of official IDP camp dwellers were women or children, and the men in camps were often elderly (NRC and IDMC 2012).

The demographics of these IDP camps reflect and reinforce the gendered nature of both civil conflict and labor markets in the fisheries sector. Men, especially young men, make up the vast majority of the front-line fighting forces of both rebel and government armies. Even when women are among the combatants, they are typically outnumbered by men by large margins (Goldstein 2003, Wood and Thomas 2017). However, women often perform significant roles in logistics and supply chains, even if these roles are poorly understood and underrecognized in postconflict settings (Jennings 2009). Similarly, artisanal fishing is physically arduous and dangerous, and often requires fishers to relocate quickly to follow fish. These factors, as well as gender biases and norms about appropriate occupations, depress women's employment opportunities in on-boat fishing activities, though many are employed in important roles like 
processing and linked occupations (Bennett 2005). Survey data indicate men outnumber women as fishers on Lake Victoria by a factor of nearly 10 (720 to 78). Our calculations are based on a survey of 1305 self-identified fishers or workers in related occupations (dryers, processors, etc.) at 80 landing sites across Kenya $(\mathrm{n}=451)$, Tanzania $(\mathrm{n}=350)$, and Uganda $(\mathrm{n}=504)$. Landing sites for the survey were chosen by random sample. In addition, between two and four landing sites with exceptionally large numbers of boats $(>100)$ were included per country to capture the economic activities and relations that are particular to large landing sites, which usually trade all available fish species, for both local and export markets. In Uganda only, three of those landing sites with exceptionally high proximity to a town $(<10$ $\mathrm{km}$ ) were also included. In Tanzania and Kenya, these cases coincided with the exceptionally large landing sites ( $>100$ boats). Surveys were conducted between April-July 2016. In both conflict and fisheries, women were disproportionately relegated to subordinate, less remunerative, and/or socially less-recognized positions. Facing comparatively better labor market prospects, men were less likely to enter and remain in IDP camps, instead seeking opportunities in labor markets to the south.

\section{Link 2: internal displacement drove fishing effort in Lake Victoria}

Internal displacement due to the conflict in northern Uganda corresponded with an increase in fishing effort in the lake, consistent with Link 2(Fig. 6). The rapid increase in IDPs between 2003 and 2006 co-occurred with a $43 \%$ increase in the number of fishers from 2004 to 2006 (and followed a 12\% decline in the prior two-year period, 2002-2004). Decisions to migrate, either across or within borders, are driven by push-pull dynamics: push factors are those attributes of the home region, which make it comparatively undesirable, while pull factors are those that attract individuals to a certain area. During this period, the shores of Lake Victoria remained both comparatively peaceful and economically vibrant, making the region a desirable destination for internal migrants. Outside of a few attacks in the capital Kampala, the lakeshore was spared the violence that characterized northern districts: between 1989 and 2010, fewer than $2 \%$ of all attacks (across all basin countries) occurred within $50 \mathrm{~km}$ of the lake (see Fig. 1). Employment opportunities near the lake were more plentiful as well. Uganda's urban areas are concentrated in the south, where there were employment opportunities in the informal sector.

The lake itself, and the employment options to be found there, were major draws for displaced persons from the north and for southerners facing increased labor market competition from displaced persons in southern Uganda's more urban centers. In contrast to land, which is a closed access resource, the lake itself is open access, with no formal limitations on who can fish. Moreover, the Lake Victoria fishery is comparatively lightly capitalized, so capital-based barriers to entry are relatively low: of the 29,836 boats identified in the 2006 LVFO comprehensive landing site survey, $66.9 \%$ were powered by paddles; only one third were powered by either petrol engines or sails (LVFO 2013). In the short term, renting a boat was relatively easy for individuals without startup capital, even if assumption of such debt could have long-term financial implications for fishers who became indebted to wealthy boat owners. For example, boat owners and fishing crews enter into contracts in which the owner loans out a boat for some period of time in exchange for exclusive rights to purchase the crew's catch at a discounted rate. However, there are significant gender- and age-based informal barriers to fishing: onboat fishing activities are dominated by young and middle-aged men. Combined, these factors made fishing a viable employment option for individuals, predominantly men, without access to land or significant investment capital. These employment opportunities came with significant physical and financial risk, but they were comparatively plentiful.

Indirect indicators suggest conflict-related internal displacement and economic migration were key drivers of population growth along the Ugandan lakeshore. First, although migrants compose only $29.1 \%$ and $21.7 \%$ of persons employed in fisheries in Kenya and Tanzania, respectively, they make up more than half $(55.2 \%)$ of those employed in Uganda (survey described above).

Second, population growth along the Ugandan shoreline during the period was quite rapid. Between 2000 and 2010, the Ugandan population within $5 \mathrm{~km}$ of the lakeshore grew $66.3 \%$, at an annual rate nearly double the national average over the same time period. The possibility that underlying differences in fertility across regions drove this increase is remote. Because of higher rates of urbanization and levels of education, households in southern Uganda typically have lower fertility rates than households in the north, west, or east (UBOS 2012). The number of Ugandan fishers also increased during this time period (Fig. 6). Although some of this increase was due to general population growth, the period of most rapid increase in number of Ugandan fishers corresponded in time (2004-2006) to the peak in IDP generation. In fact, the number of fishers actually declined between 2002 and 2004, and between 2006 and 2008.

Fig. 6. The number of fishers increased in Uganda at the same time internally displaced people (IDPs) were increasing. The number of fishers (from biennial frame surveys) jumped between 2004 and 2006 (22\% per year) as IDPs in Uganda peaked, against a general population increase of $6.6 \%$ of people living within five $\mathrm{km}$ of the lake shore.

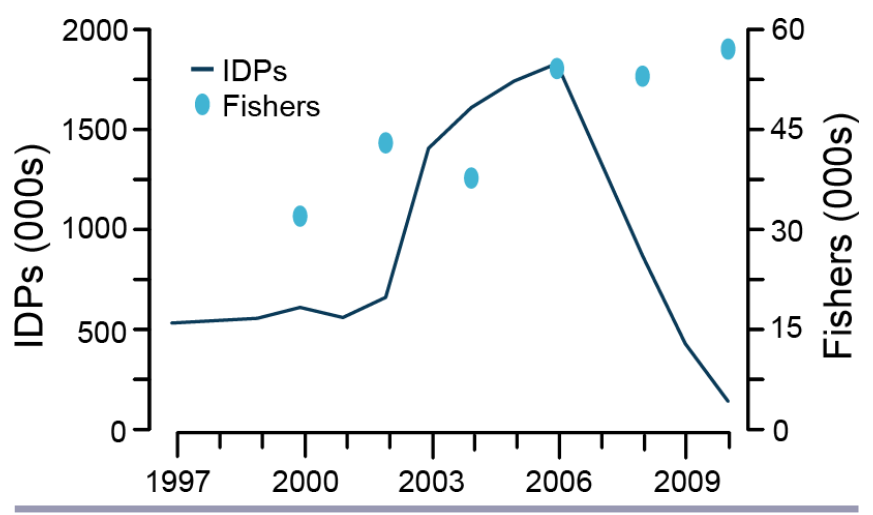

Link 3: fishing effort drove short-term increases in Nile perch catch

The displacement of millions of people from their homes in northern Uganda corresponds strongly with an increase in reported catch of Nile perch during the same time period (Fig. 2, Pearson correlation $\mathrm{p}<0.05)$. Catches of Nile perch were stable 
from 1997 to 2002 but rose rapidly from 2003 through 2006. This period corresponded to a dramatic upturn in conflict intensity following the Ugandan government's unsuccessful attempt to decisively defeat the LRA during Operation Iron Fist and a tripling of the numbers of IDPs (from 661,000 in 2002 to $1,830,000$ in 2006). As the conflict waned in 2006 and 2007 because of enhanced cooperation between the Sudanese and Ugandan governments along their shared border, which the LRA had been using as safe haven, both the numbers of IDPs and catches for Nile perch declined.

Alternate or additional causes for an increase in Nile perch catch must be explored. First, the observed dynamics may have reflected an across-the-board increase in fish catch lake wide. However, during the same period, catch for Nile perch declined in Tanzania and Kenya (Fig. 7). Second, a rapid capitalization of the Ugandan fishery occurred in the mid-2000s. The removal of a European Union ban on imports of Nile perch from Lake Victoria, in place from 1997-2000 and stemming from concerns about fisheries regulation and heavy metal contamination, resulted in significant reinvestment in fish processing capacity. Six new processing plants were opened in Uganda in the early to mid-2000s, resulting in enhanced processing (filleting and freezing) capacity for the export market (Ponte 2005). Similarly, the end of the ban also coincided with increased capital investments in the fishing fleet, with the proportion of Ugandan fishing boats using outboard motors doubling (LVFO 2013).

Fig. 7. Trends in catch of Nile perch and tilapia in Uganda, Kenya, and Tanzania. Catch in Uganda trended sharply upward from 2003 through 2007, corresponding in time to the most violent conflict in northern Uganda. Catch in Kenya and Tanzania declined during this period.

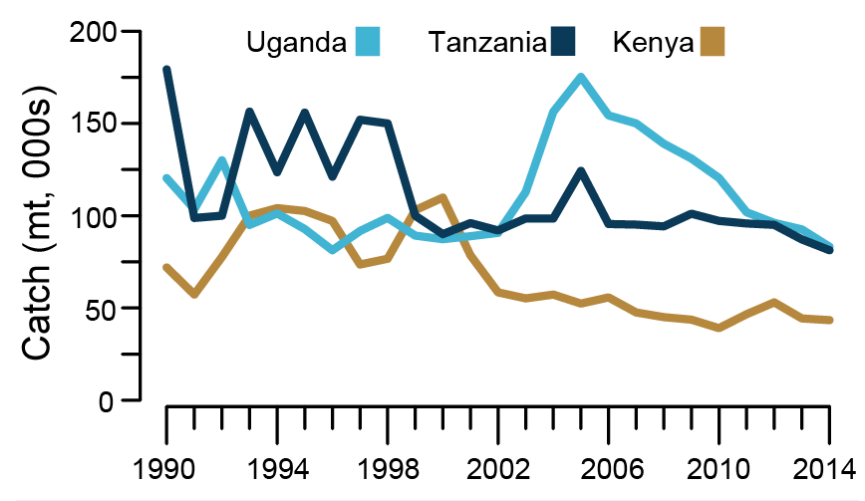

These developments were important in incentivizing fishing effort, but it does not explain on its own the dynamics seen uniquely in Uganda. The Nile perch ban applied equally to Kenya and Tanzania. All three countries saw increases (22.4\% in Kenya, $32.4 \%$ in Tanzania, and $42.9 \%$ in Uganda) in the numbers of fishing vessels from 2004 to 2006, and increases in the numbers of fishers working the lake $(18.5 \%, 25.7 \%$, and $43.5 \%$, respectively). However, by far the largest proportional increases were in Uganda (Table 1). Uganda's increase amounted to a $13.6 \%$ increase in fishers per $\mathrm{km}$ of coastline (excluding islands), an increase that was $36 \%$ larger than those seen in either Kenya or Tanzania over the same time. The two-year increase in Uganda's fishing industry from 2004-2006, the period corresponding with the peak of the IDP crisis, was over a third larger than corresponding increases in Kenya and Tanzania, even though all three countries faced similar market incentives.

Table 1. Difference-in-difference changes in fishers per $\mathrm{km}$ of shoreline in Kenya/Tanzania and Uganda, 2004 to 2006.

\begin{tabular}{lccc}
\hline \hline Year & $\begin{array}{c}\text { KE/TZ average (fishers } \\
\text { per km) }\end{array}$ & $\begin{array}{c}\text { Uganda (fishers } \\
\text { per km) }\end{array}$ & Difference \\
\hline 2004 & 41.9 & 31.3 & -10.6 \\
2006 & 51.9 & 44.9 & -7.0 \\
Change & 10.0 & 13.6 & 3.6 \\
\hline
\end{tabular}

Although technological improvements certainly contributed to the growth in the fishery, the general increase in employment in the fishery suggests that not all gains were due to technological changes. Moreover, the increasing attractiveness of the fisheries sector as an investment destination for smaller-scale Ugandan investors must be understood in the context of a decline in the attractiveness of investment in other sectors, particularly farming and land leasing, which were affected directly by the conflict.

Finally, increases in Nile perch abundance could have caused the spike in catch. The abundance of Nile perch, as estimated by fisheries-independent hydroacoustic surveys (Taabu-Munyaho 2014), did peak around 2007 (Fig. 8), but this peak followed about five years of stable population estimates (Taabu-Munyaho 2014) that do not mirror the rapid increase in catch.

Fig. 8. Possible conflict threshold effect from changes in Nile perch catch relative to abundance. Biomass and catch plotted here are for the entire lake. Conflict between Uganda and Kenya over fishing and territorial rights on Migingo Island began heating up around 2007 and peaked in 2009 (see text). From 2007 to 2008 catch changed from $17 \%$ to $40 \%$ of fish abundance. This change likely resulted in higher levels of fishing effort (e.g., hours spent fishing) to maintain stable catch. We theorize this increased pressure could have caused the simmering conflict over Migingo, and its associated Nile perch access, to boil over in 2009 .

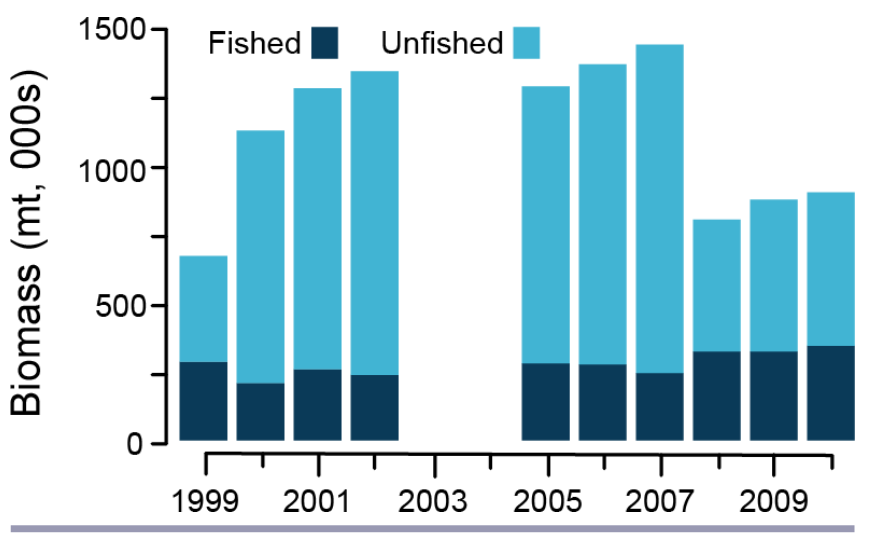

Links 4 and 5: fishing effort contributed to declines in Nile perch populations and catch

Nile perch occur throughout sub-Saharan Africa in all major river basins. They are demersal fish that can grow to two meters in 
length and omnivorous predators that consume plankton, crustaceans, and insects as juveniles and a wide variety of fishes as adults. In Lake Victoria, their introduction in the 1950s did not immediately result in stock declines (Goudswaard et al. 2008). Today, its high fecundity and relatively high tolerance of eutrophic conditions has made it the second largest fishery by volume in Lake Victoria.

The dynamics governing Nile perch populations in Lake Victoria are complex, spatially heterogeneous, and often debated (OgutuOhwayo 1990, Balirwa 2007, Downing et al. 2012, van Zwieten et al. 2016). The collapse of indigenous haplochromines has been attributed to predation by Nile perch, but other lines of evidence show lake eutrophication and anoxia were the culprits (Hecky et al. 1994). Van Zweiten et al. (2016) proposed the decline of haplochromines populations may have released juvenile Nile perch from predation pressures enough to allow their populations to flourish. Nile perch relative abundance and catch are higher during periods of stratification, when they avoid low oxygen depths and are more compressed in distribution (Taabu-Munyaho 2013). Eutrophication of the lake has disrupted fish populations throughout the food web, causing fluctuations in the main prey species of Nile perch. Contributing to exogenous factors, complex food web dynamics are at play (Downing et al. 2014). During the period of interest to this study, Nile perch stocks were heavily fished, and Matshuishi et al. (2006) found classic indicators of overfishing, including increased numbers of fishers, growth in gear, and increases in illegal fishing. As noted earlier, overfishing became a major concern in the mid-2000s as catch declined, but fishery-independent, acoustic-based stock assessments showed an increase in Nile perch populations, particularly of juvenile sizes, between 2011-2014 (LVFO 2015).

Although these complex and varied drivers of changes in Nile perch dynamics are an important part of the story, for the purposes of links 4 and 5 we are especially interested in changes to the stock that would be perceived by fishers in Uganda. A significant biological change in Nile perch population status occurred between 2007 and 2008 (Fig. 8). This shift appears to be a threshold, but the time series is not long enough for some of the analytical tools needed to verify a true threshold, such as intervention analysis. The ratio of fished to unfished biomass in the lake, measured respectively by catch and abundance (estimated from fishery-independent acoustic surveys; TaabuMunyaho 2014), shows a sudden shift at that time. From 1999-2007, catch averaged $23 \%$ of total biomass; after 2008, that average rose to $38 \%$. Around 2008 specifically, catch changed from $17 \%$ to $40 \%$ of total biomass. Fishers were then capturing a much higher proportion of the fish available to them, circumstances that usually result in greater per-capita effort (CPUE in the form of hours spent fishing) to maintain stable catch (Kayanda et al. 2017). We suggest this change, specifically, may have contributed to the rising tensions in the area over Nile perch catch and ownership of Migingo Island.

\section{Link 6: changes in fish catch drove conflict at Migingo Island}

Two of the hallmarks of coupled natural-human or socialecological systems are feedback loops and scale effects: local dynamics feed back into the system, affecting outcomes in different and often distant systems and across scales (Liu et al. 2007, Ostrom 2009). In this case, conflict dynamics in the human system led to increased fishing pressure, altering population dynamics in the aquatic subsystem. Reciprocally, the depressed Nile perch catches fed back into the human system, leading to increased competition for resources and distributive conflict. Instead of feeding back into the LRA conflict, however, declining catches and CPUE in Uganda contributed to conflict with neighboring Kenya over Migingo Island, a small (0.2 hectare) island near the Ugandan/Kenyan border in Lake Victoria.

For most of the twentieth century, Migingo was uninhabited and nominally administered by Kenyan authorities in accordance with border demarcations conducted by the colonial British authority in 1926. The island remained unpopulated until 1991, when two Kenyan fishers occupied it. In 2004, a Ugandan fisher arrived and claimed to find the island abandoned. Predictably, the story of the tiny island's occupation differs depending on the source (Kenyan or Ugandan) consulted.

However, it was not until 2007 (the year after the peak in Ugandan IDPs) that the island became disputed. Beginning with the arrest of 16 fishers in September 2007, and continuing through 2008, reports of harassment of Kenyan fishers by Ugandan authorities were prevalent. The conflict became most acute in 2009, a time corresponding to greater fishing pressure and decreased catches in Kenya and Uganda. In January 2009, the Kenyan Prime Minister called for the harassment to cease, and the next month, the island dispute appeared on the agenda at the East African Legislative Assembly (EALA) meeting in Rwanda (BBC 2009a). On February 17, 12 Kenyan police officers were arrested by Ugandan military officials and released 5 days later (BBC 2009b, c); Ugandan officials denied this report. The East African Community (EAC) minister called the deployment of troops on the island an insult to the EAC Treaty (BBC 2009c). On February 24, Kenyan Prime Minister Raila Odinga laid claim to Migingo (BBC 2009d). Ugandan officials responded by hoisting two Ugandan flags and requiring all Kenyans to sign a visitor book upon island entry, arresting Kenyan fishermen for allegedly crossing into Ugandan waters, and instating a residence application and fee for Kenyans remaining on the island (BBC $2009 e, f)$.

The dispute continued into late 2009, with tensions flaring to the point that Rwandan President and EAC chairman Paul Kagame offered to mediate between the two parties; in May, the Kenyan Parliament passed a motion urging President Mwai Kibaki to seek intervention by the UN Security Council (Standard 2009). Since peaking in 2009 , official tensions have waned, but crossborder harassment of fishers by both Kenyan and Ugandan authorities may still occur despite a reported comanagement solution (New Vision 2014). Sporadic violence, including the murder of fishers, has continued (Masaba and Odeng 2016).

Other scholars have acknowledged the role of fisheries in the escalation of the Migingo conflict (Okumu 2010, Wekesa 2010), as have representatives of both governments. In 2009, then Ugandan Fisheries Commissioner Wilson Mwanja stated: "The [Migingo] conflict has always been there but was masked by abundant fish stocks. Now that they are declining, the conflicts are more glaring," (Daily Nation 2009) suggesting declining catches explains why the disputed border had not become a contentious issue until the late-2000s. The same year, Kenyan Prime Minister Raila Odinga remarked: "The fight over [Migingo] 
island is not about land, but about fish" (Otieno 2009). As with any political conflict, monocausal explanations are lacking. Still, declining catches of Nile perch have been identified as the central issue in the Migingo conflict, and there are few plausible alternative explanations for competing territorial claims on the small, marginally inhabitable island.

The conflict over Migingo Island is the first conflict in Lake Victoria over fishing access that has grown to involve national governments and their security forces. It contrasts starkly with a history of cooperation, rather than conflict, around the lake's resources and user groups. Canter and Ndegwa (2002) demonstrated robust cooperation over resource use rather than conflict, from local fishing villages through national-level management. They concluded that Lake Victoria offers a "contrary case" to Malthusian-based predictions of conflict over finite resources. However, Canter and Ndegwa's study was conducted in 2000, immediately following a period of years (1985-1999) of a boom in CPUE (catch per boat); this CPUE dropped off dramatically in 2000 (Matsuishi et al. 2006). As conditions in the lake changed over the following eight years (lower CPUE, greater human population and number of fishers), the conditions of apparent abundance that facilitated peaceful cooperation over the island changed accordingly.

\section{CONCLUSIONS}

We find general support for our theoretical mechanisms (Figs. 3, 4) linking conflict in Uganda and fisheries in Lake Victoria. The occurrence of conflict in northern Uganda positively corresponded to population displacement (Fig. 5), which positively corresponded to an increase in fishing effort (Fig. 6). Increased fishing effort corresponded to different responses in Nile perch at different times: in the short term, Nile perch catch increased, whereas over a few years catch decreased (Figs. 2, 7). The hypothesized relationship between conflict and catch presented in Figure 4, then, is in line with our expectations: catch that followed patterns of IDP generation are not inconsistent with an increase in fishing effort at the same time. Finally, the relationship between catch and ensuing conflict was negative: as Nile perch catches in Ugandan waters declined, and lake-wide as fishers caught an increasing proportion of the total population of Nile perch, conditions became ripe for conflict, brought to flashpoint on an island straddling an international border.

Existing typologies of fisheries conflict describe several of the linkages examined in this study. To be clear, the conflict in northern Uganda was not over fisheries but rather had an impact on fisheries in a different geographic location. The conflict at Migingo, on the other hand, neatly falls into several existing typologies. According to Charles (1992), the Migingo conflict is a classic one of jurisdiction over who owns the Nile perch population around the island. According to Warner (2000), it is an example of a micro-micro conflict or boundary dispute. And according to the newest typology by Bennett et al. (2001), the conflict at Migingo is a type 1 conflict over who controls the fishery. This latter typology sheds the greatest light on the cause and potential solutions to the conflict: institutional frameworks. In their study, type 1 conflicts were driven by weak institutional agreement over access to the water body. Although Lake Victoria's fisheries benefit from being governed by a multilateral governing/ scientific body, the Lake Victoria Fisheries Organization (LVFO), that body's mandate and ability to manage fisheries-related conflict is limited. The LVFO's mandate is to coordinate fisheries management among Kenya, Tanzania, and Uganda, and promote aquacultural development, not to manage conflict per se.

Human conflicts are often symptomatic of deeper systemic perturbations, which can lead to efforts directed at treating symptoms rather than the actual drivers of social-ecological problems. Although there is still tremendous empirical work that needs to be done to elucidate, confirm, and quantify links between conflict and fisheries, this study adds to the current body of knowledge accordingly:

1. These correlation-based relationships are illustrative but not conclusive. Although a host of additional variables are implicated in driving these relationships, the conflict signal is real. Post hoc analysis is poor at revealing direct links in such diffuse causal mechanisms, but that does not negate their importance. In times of conflict, studies that are directed at these questions are needed.

2. Spatial scale and distance play key roles in structuring conflict-fisheries dynamics. Critically, the couplings between conflict and fisheries subsystems are spatially asymmetric. In our case study of Uganda, conflict in northern Uganda created conditions nationally that supported greater fishing effort in a concentrated location in southern Uganda, Lake Victoria, as well as population displacement to Kenya and Tanzania (NRC and IDMC 2012). Conversely, changes in fisheries conditions in the lake caused even more localized conflict at Migingo Island, at the scale of interstate (rather than domestic) conflict. Thus, conflict effects are diffuse in their links to broad changes in the fishery, whereas fishery effects may produce more proximate, location-specific conflicts. The effects of other regional conflicts on fisheries, such as the mass displacement of Rwandans into Tanzania during the Rwandan civil war and genocide and the election-related violence of 2007/08 in Kenya, which led to mass population displacement in Kenya's lakeside districts, have yet to be studied. However, we hypothesize the relative remoteness of actual violence to fishing villages in the former, and close proximity in the latter, would have been associated with an increase in fishing effort in Tanzania and a decrease in Kenya.

3. The drivers of fishing effort and catch originate in different subsystems, but their changes and effects must be analyzed in concert (Berkes and Folke 1998). For example, the pressure on fishers from declining Nile perch catch is understood much more clearly in the context of effort. Although catch has been stable or slightly declining, the number of fishers on the lake suggests greater competition and the increasing number of hours spent fishing suggests fishers are spending more to catch the same. Therefore, the link to livelihoods from changes in fish catch must be understood through concurrent changes in effort, despite differing origins of drivers for these two variables (the human and natural subsystems, respectively). Although not directly affecting the natural subsystem, the gendered nature of both participation in armed conflict and the fisheries sector may exacerbate existing inequalities of power and access in the human subsystem, thus making marginalized 
individuals and groups, especially women, more vulnerable to food and livelihood insecurity.

4. The complex and path-dependent nature of impacts of conflicts on natural resources in general, and fisheries in particular, highlights the urgent need of targeted surveys and more mechanistic understanding (McConnell et al. 2011). Conflict is neither a certain nor predictable outcome in changes in fisheries resources. To predict when and where the conflict-fisheries nexus is likely to be triggered, we suggest better monitoring of IDPs during conflict, their locations, their motivations for leaving, and their postmigration source of income (if any).

5. The open access nature of fisheries in Lake Victoria may exacerbate instabilities not present in other systems. Unlike agricultural systems, in which land tenure and farming or grazing is more easily monitored and controlled, openaccess fisheries provide opportunities for those seeking employment with far fewer barriers, complicating peaceful efforts at comanagement (Jentoft et al. 1998, Balirwa 2007). Even in systems with access restrictions, the ease with which illegal fishing can occur makes artisanal fisheries a unique source of pull factors.

6. The diffuse and context-specific effects of conflicts on fisheries means models of fisheries management (e.g., stock assessment) should not incorporate conflict as a driver at this time. Stock assessment models require a rich suite of biological information on the fish in a system, and even single-species models are quite complex and data thirsty. Although clear relationships between conflict and fisheries are becoming more apparent (see also Bennett et al. 2001, Pomeroy et al. 2007, Jacquet et al. 2010, Hendrix and Glaser 2011, McClanahan et al. 2015, Pomeroy et al. 2016), before conflict mechanisms can be incorporated into fisheries models, we need a better understanding of the form and fit of these relationships. However, fisheries do need to be incorporated into a larger social-ecological science instead of remaining stove-piped as independent of other aspects of the human-natural system.

7. The case study of civil conflict in northern Uganda suggests one basic, and often recommended, approach to shortcircuiting the conflict-fisheries feedback loop: countries and their stakeholders should focus on diversification in employment for short-term coping mechanisms during conflict.

These insights may generalize to other cases in which armed conflict is present and artisanal fisheries are a critical source of livelihood and food security. The critical factor is proximity of fighting to fishing areas. As in the Uganda case, when fighting occurs far from fishing activities and communities, these activities and communities can be an attractive destination for displaced persons. This is likely especially true of lower-income countries in which barriers to fishery entry are comparatively low. These dynamics have been observed in Mozambique and Zimbabwe (Béné, et al. 2010), the Democratic Republic of the Congo (Van der Knaap et al. 2014), and Vietnamese refugees in China (Lam 2000). Alternately, when conflict occurs near or explicitly targets fishing areas, as in Liberia (Belhabib et al. 2018) and the Jaffna peninsula of Sri Lanka (Hendrix and Glaser 2011), fishing effort may decline precipitously because of population displacement and, in some instances, active recruitment of fishers into rebel armies. Overall, our analysis contributes to identifying the scaleand location-dependent ways conflict affects natural resource utilization and management, and vice versa: depending on where fighting occurs and where resources are located, conflict can either accelerate or inhibit the rate of resource extraction (Bannon and Collier 2003, Mitchell and Thies 2012).

Developing countries are more prone to violent armed conflict and also home to the overwhelming majority of the world's fishers (Collier et al. 2003, FAO 2015). However, research on the links between armed conflict and fisheries in developing countries is still nascent. Conflict is highly likely to co-occur in regions of data-poor fisheries, compounding the challenges of collecting sufficient data to demonstrate empirical relationships. In this exploratory analysis, we developed a conflict-fisheries model in which human and natural subsystems are coupled through the mechanisms of fishing effort and fish catch, and in which conflict becomes both a driver and a result of the dynamic interplay between fishing effort and underlying biological processes in the fishery. We document a conflict feedback loop as hypothesized by Pomeroy et al. (2016). On this basis, we recommend further analysis of these dynamics in different systems and beginning to integrate conflict awareness and sensitivity into fisheries management frameworks.

Responses to this article can be read online at: http://www.ecologyandsociety.org/issues/responses. php/10787

\section{Acknowledgments:}

This material is based upon work supported by, or in part by, the $U$. S. Army Research Office contract/grant number W911NF-09-1-007 under the Minerva Initiative of the U.S. Department of Defense and the National Science Foundation Dynamics of Coupled Natural and Human Systems grant number 1358861. We thank the National Fisheries Resources Research Institute (NaFIRRI) in Uganda, Kenya Marine and Fisheries Research Institute (KMFRI), the Tanzania Fisheries Research Institute (TAFIRI), and the Lake Victoria Fisheries Organization (LVFO). Colleen Devlin, Alyssa Luisi, Meghan Mooney, and Daniel Ramos all contributed excellent research assistance to this project. All authors confirm we have no conflicts of interest to declare. Paige Roberts made Figure 1.

\section{LITERATURE CITED}

Achieng, A. P. 1990. The impact of the introduction of Nile perch, Lates niloticus (L.), on the fisheries of Lake Victoria. Journal of Fish Biology 37:17-23. http://dx.doi.org/10.1111/j.1095-8649.1990. tb05016.x

Alderman, H., J. Hoddintot, and B. Kinsey. 2006. Long term consequences of early childhood malnutrition. Oxford Economic Papers 58:450-474. http://dx.doi.org/10.1093/oep/gp1008

Balirwa, J. S. 2007. Ecological, environmental and socioeconomic aspects of the Lake Victoria's introduced Nile perch fishery in 
relation to the native fisheries and the species culture potential: lessons to learn. African Journal of Ecology 45:120-129. http://dx. doi.org/10.1111/j.1365-2028.2007.00753.x

Balirwa, J. S., C. A. Chapman, L. J. Chapman, I. G. Cowx, K. Geheb, L. Kaufman, R. H. Lowe-McConnell, O. Seehausen, J. H. Wanink, R. L. Welcomme, and F. Witte. 2003. Biodiversity and fishery sustainability in the Lake Victoria basin: an unexpected marriage? Bioscience 53:703-716. http://dx.doi. org/10.1641/0006-3568(2003)053[0703:BAFSIT]2.0.CO:2

Bannon, I., and P. Collier. 2003. Natural resources and conflict: options and actions. World Bank, Washington, D.C., USA. http:// dx.doi.org/10.1596/0-8213-5503-1

Belhabib, D., R. Dridi, A. Padilla, M. Ang, and P. Le Billon. 2018. Impacts of anthropogenic and natural "extreme events" on global fisheries. Fish and Fisheries 19:1092-1109. http://dx.doi. org/10.1111/faf.12314

Bellemare, M. F. 2015. Rising food prices, food price volatility, and social unrest. American Journal of Agricultural Economics 97:1-21. http://dx.doi.org/10.1093/ajae/aau038

Béné, C., B. Hersoug, and E. H. Allison. 2010. Not by rent alone: analysing the pro-poor functions of small-scale fisheries in developing countries. Development Policy Review 28:325-358. http://dx.doi.org/10.1111/j.1467-7679.2010.00486.x

Bennett, E., A. Neiland, E. Anang, P. Bannerman, A. Atiq Rahman, S. Huq, S. Bhuiya, M. Day, M. Fulford-Gardiner, and W. Clerveaux. 2001. Towards a better understanding of conflict management in tropical fisheries: evidence from Ghana, Bangladesh and the Caribbean. Marine Policy 25:365-376. http:// dx.doi.org/10.1016/S0308-597X(01)00022-7

Bennett, E. 2005. Gender, fisheries, and development. Marine Policy 29:451-459. http://dx.doi.org/10.1016/j.marpol.2004.07.003

Berkes, F., and C. Folke. 1998. Linking social and ecological systems for resilience and sustainability. Pages 1-25 in F. Berkes and C. Folke, editors. Linking social and ecological systems: management practices and social mechanisms for building resilience. Cambridge University Press, Cambridge, UK.

Blattman, C., and E. Miguel. 2010. Civil War. Journal of Economic Literature 48:3-57. http://dx.doi.org/10.1257/jel.48.1.3

British Broadcasting Corporation (BBC). 2009a. East Africa community MPs to discuss disputed Lake Victoria island. $B B C$ Monitoring Africa 11 February.

British Broadcasting Corporation (BBC). 2009b. Tension reported on island claimed by Uganda and Kenya. $B B C$ Monitoring Africa 20 February.

British Broadcasting Corporation (BBC). 2009c. Kenya condemns "siege" in disputed Lake Victoria island. $B B C$ Monitoring Africa 22 February.

British Broadcasting Corporation (BBC). 2009d. Kenya to reclaim disputed Lake Victoria island - Premier. BBC Monitoring Africa 24 February.

British Broadcasting Corporation (BBC). 2009e. Kenya, Uganda to use maps drawn by Britain to solve island dispute. $B B C$ Monitoring Africa 4 March.
British Broadcasting Corporation (BBC). 2009f. Ugandan authorities arrest Kenyan fisherman over disputed island. $B B C$ Monitoring Africa 6 March.

Canter, M. J., and S. N. Ndegwa. 2002. Environmental scarcity and conflict: a contrary case from Lake Victoria. Global Environmental Politics 2(3):40-63. http://dx.doi.org/10.1162/152$\underline{638002320310527}$

Center for International Earth Science Information Network (CIESIN) and Centro Internacional de Agricultura Tropical (CIAT). 2005. Gridded population of the world. Version 3 (GPWv3). CIESIN, Columbia University, New York, New York, USA. [online] URL: http://sedac.ciesin.columbia.edu/data/ collection/gpw-v3

Cerra, V., and S. C. Saxena. 2008. Growth dynamics: the myth of economic recovery. American Economic Review 98:439-457. http://dx.doi.org/10.1257/aer.98.1.439

Charles, A. T. 1992. Fishery conflicts; a unified framework. Marine Policy 16:379-393. http://dx.doi.org/10.1016/0308-597X (92)90006-B

Collier, P., V. L. Elliott, H. Hegre, A. Hoefer, M. Reynal-Querol, and N. Sambanis. 2003. Breaking the conflict trap: civil war and development policy. World Bank, Washington, D.C., USA. [online] URL: https://openknowledge.worldbank.org/bitstream/ handle/10986/13938/567930PUB0brea10Box353739B01PUBLIC1. pdf? sequence $=1$ \&isAllowed $=y$

Cushing, D. H. 1974. The natural regulation of fish populations. Pages 399-412 in F. R. Harden Jones, editor. Sea fisheries research. Elek Science, London, UK.

Daily Nation. 2009. Uganda defends presence on island. Daily Nation 5 April. [online] URL: https://www.nation.co.ke/ news/1056-557506-k5xotrz/index.html

Daskin, J. H., and R. M. Pringle. 2018. Warfare and wildlife declines in Africa's protected areas. Nature 553:328-332. http:// dx.doi.org/10.1038/nature25194

Downing, A. S., E. van Nes, J. Balirwa, J. Beuving, P. Bwathondi, L. J. Chapman, I. J. M. Cornelissen, I. G. Cowx, K. Goudswaard, R. E. Hecky, J. H. Janse, A. Janssen, L. Kaufman, M. A. KisheMachumu, J. Kolding, W. Ligtvoet, D. Mbabazi, M. Medard, O. C. Mkumbo, E. Mlaponi, A. T. Munyaho, L. A. J. Nagelkerke, R. Ogutu-Ohwayo, W. O. Ojwang, H. K. Peter, D. Schindler, O. Seehausen, D. Sharpe, G. M. Silsbe, L. Sitoki, R. Tumwebaze, D. Tweddle, K. E. Van de Wolfshaar, H. Van Dijk, E. Van Donk, J. C. Van Rijssel, P. A. M. Van Zwieten, J. H. Wanink, F. Witte, and W. M. Mooij. 2014. Coupled human and natural system dynamics as key to the sustainability of Lake Victoria's ecosystem services. Ecology and Society 19(4):31. http://dx.doi.org/10.5751/ ES-06965-190431

Downing, A. S., E. H. van Nes, J. H. Janse, F. Witte, I. J. M. Cornelissen, M. Scheffer, and W. M. Mooij. 2012. Collapse and reorganization of a food web of Mwanza Gulf, Lake Victoria. Ecological Applications 22:229-239. http://dx.doi.org/10.1890/11-0941.1

Dudley, J. P., J. R. Ginsberg, A. J. Plumptre, J. A. Hart, and L. C. Campos. 2002. Effects of war and civil strife on wildlife and wildlife habitats. Conservation Biology 16:319-329. http://dx.doi. org/10.1046/j.1523-1739.2002.00306.x 
Fearon, J. D. 2004. Why do some civil wars last so much longer than others? Journal of Peace Research 41:275-302. http://dx.doi. org/10.1177/0022343304043770

Fearon, J. D. 2005. Primary commodity exports and civil war. Journal of Conflict Resolution 49:483-507. http://dx.doi. org/10.1177/0022002705277544

Fjelde, H. 2015. Farming or fighting? Agricultural price shocks and civil war in Africa. World Development 67:525-534. http://dx. doi.org/10.1016/j.worlddev.2014.10.032

Food and Agriculture Organization (FAO). 2009. Food security and agricultural livelihoods cluster: plan of action for Northern Uganda. FAO, Rome, Italy. [online] URL: https://reliefweb.int/ sites/reliefweb.int/files/resources/5411ECE9ED6E055E492575410010BA4D-Full Report.pdf

Food and Agriculture Organization (FAO). 2015. Fishstat. FAO, Rome, Italy. [online] URL: http://www.fao.org/fishery/statistics/ software/fishstat/en

Food and Agriculture Organization (FAO), International Fund for Agricultural Development (IFAD). United Nations International Children's Emergency Fund (UNICEF), World Food Programme (WFP), and World Health Organization (WHO). 2017. The state of food security and nutrition in the world 2017: building resilience for peace and food security. FAO, Rome, Italy. [online] URL: http://www.fao.org/3/a-I7695e.pdf

Gates, S., H. Hegre, H. M. Nygård, and H. Strand. 2012. Development consequences of armed conflict. World Development 40:1713-1722. http://dx.doi.org/10.1016/j. worlddev.2012.04.031

Geheb, K., S. Kalloch M. Medard, A.-T. Nyapendi, C. Lwenya, and M. Kyangwa. 2008. Nile perch and the hungry of Lake Victoria: gender, status and food in an East African fishery. Food Policy 33:85-98. http://dx.doi.org/10.1016/j.foodpol.2007.06.001

Ghobarah, H. A., P. Huth, and B. Russett. 2004. The post-war public health effects of civil conflict. Social Science and Medicine 59:869-884. http://dx.doi.org/10.1016/j.socscimed.2003.11.043

Goldstein, J. S. 2003. War and gender: how gender shapes the war system and vice versa. Cambridge University Press, Cambridge, UK.

Goudswaard, K. P. C., F. Witte, and E. F. B. Katunzi. 2008. The invasion of an introduced predator, Nile perch (Lates niloticus, L.) in Lake Victoria (East Africa): chronology and causes. Environmental Biology of Fishes 81:127-139. http://dx.doi. org/10.1007/s10641-006-9180-7

Grace, J. 2005. Uganda: internally displaced persons in the 2006 national elections. IOM Project on Political Rights and Enfranchisement System Strengthening. International Organization for Migration, Le Grand-Saconnex, Switzerland.

Harley, S. J., R. A. Myers, and A. Dunn. 2001. Is catch-per-uniteffort proportional to abundance? Canadian Journal of Fisheries and Aquatic Sciences. 58:1760-1772. http://dx.doi.org/10.1139/ $\underline{\mathrm{f} 01-112}$

Hecky, R. E., F. W. B. Bugenyi, P. Ochumba, J. F. Talling, R. Mugidde, M. Gophen, and L. Kaufman. 1994. Deoxygenation of the deep water of Lake Victoria, East Africa. Limnology and Oceanography 39:1476-1481. http://dx.doi.org/10.4319/10.1994.39.6.1476

Hendrix, C. S., and H.-J. Brinkman. 2013. Food insecurity and conflict dynamics: causal linkages and complex feedbacks. Stability: International Journal of Security and Development 2:26. http://dx.doi.org/10.5334/sta.bm

Hendrix, C. S., and S. M. Glaser. 2011. Civil conflict and world fisheries, 1952-2004. Journal of Peace Research 48:481-495. http:// dx.doi.org/10.1177/0022343311399129

Hendrix, C. S., and S. Haggard. 2015. Global food prices, regime type, and urban unrest in the developing world. Journal of Peace Research 52:143-157. http://dx.doi.org/10.1177/0022343314561599

Homer-Dixon, T. F. 1991. On the threshold: environmental changes as causes of acute conflict. International Security 16:76-116. http://dx.doi.org/10.2307/2539061

Homer-Dixon, T. F. 2001. Environment, scarcity, and violence. Princeton University Press, Princeton, New Jersey, USA. http:// dx.doi.org/10.1515/9781400822997

Humphreys, M. 2005. Natural resources, conflict, and conflict resolution. Journal of Conflict Resolution 49:508-537. http://dx. doi.org/10.1177/0022002705277545

Humphreys, M., and J. M. Weinstein. 2006. Handling and manhandling civilians in civil war. American Political Science Review 100:429-447. http://dx.doi.org/10.1017/S0003055406062289

Jacquet, J., H. Fox, H. Motta, A. Ngusaru, and D. Zeller. 2010. Few data but many fish: marine small-scale fisheries catches for Mozambique and Tanzania. African Journal of Marine Science 32:197-206. http://dx.doi.org/10.2989/1814232X.2010.501559

Jennings, K. M. 2009. The political economy of DDR in Liberia: a gendered critique. Conflict, Security and Development 9:475-494. http://dx.doi.org/10.1080/14678800903345770

Jennings, S., M. J. Kaiser, and J. D. Reynolds. 2001. Marine Fisheries Ecology. Blackwell Science, Oxford, UK.

Jennings, S., J. D. Reynolds, and S. C. Mills. 1998. Life history correlates of responses to fisheries exploitation. Proceedings of the Royal Society B: Biological Sciences 265:333-339. http://dx. doi.org/10.1098/rspb.1998.0300

Jentoft, S., B. J. McCay, and D. C. Wilson. 1998. Social theory and fisheries co-management. Marine Policy 22:423-436. http:// dx.doi.org/10.1016/S0308-597X(97)00040-7

Kaufman, L. 1992. Catastrophic change in species-rich freshwater ecosystems: the lessons of Lake Victoria. BioScience 42:846-858. http://dx.doi.org/10.2307/1312084

Kayanda, R. J., A. I. Chande, Y. D. Mgaya, E. Mlaponi, and O. C. Mkumbo. 2017. Stock assessment of commercial fish species of Lake Victoria. Pages 107-135 in Y. D. Mgaya and S. Mahongo, editors. Lake Victoria fisheries resources: research and management in Tanzania. Springer, Berlin, Germany. http://dx. doi.org/10.1007/978-3-319-69656-0_6

Kitchell, J. F., D. E. Schindler, R. Ogutu-Ohwayo, and P. N. Reinthal. 1997. The Nile perch in Lake Victoria: interactions between predation and fisheries. Ecological Applications 
7:653-664. http://dx.doi.org/10.1890/1051-0761(1997)007[0653: TNPILV]2.0.CO;2

Kolding, J. 2013. Incredible evolution or incredulous application? Ecological Applications 23:670-671. http://dx.doi.org/10.1890/12-0280.1

Kondoh, M. 2003. Foraging adaptation and the relationship between food-web complexity and stability. Science 299:1388-1391. http://dx.doi.org/10.1126/science.1079154

Lake Victoria Fisheries Organization (LVFO). 2013. Regional status report on Lake Victoria: biennial frame surveys between 2000 and 2012. LVFO, Jinja, Uganda.

Lake Victoria Fisheries Organization (LVFO). 2015. Stock assessment report. LVFO, Jinja, Uganda.

Lake Victoria Fisheries Organization (LVFO). 2016. Regional status report on Lake Victoria: biennial frame surveys between 2000 and 2016. LVFO, Jinga, Uganda.

Lam, T. 2000. The exodus of Hoa refugees from Vietnam and their settlement in Guangxi: China's refugee settlement strategies. Journal of Refugee Studies 13:374-390. http://dx.doi.org/10.1093/ jis/13.4.374

Le Billon, P. 2001. The political ecology of war: natural resources and armed conflicts. Political Geography 20:561-584. http://dx. doi.org/10.1016/S0962-6298(01)00015-4

Le Billon, P. 2012. Wars of plunder: conflicts, profits and the politics of resources. Columbia University Press, New York, New York, USA. http://dx.doi.org/10.1093/acprof:oso/9780199333462.001.0001

Linard, C., M. Gilbert, R. W. Snow, A. M. Noor, and A. J. Tatem. 2012. Population distribution, settlement patterns and accessibility across Africa in 2010. PLOS ONE7(2):e31743. http:// dx.doi.org/10.1371/journal.pone.0031743

Liu, J., T. Dietz, S. R. Carpenter, M. Alberti, C. Folke, E. Moran, A. N. Pell, P. Deadman, T. Kratz, J. Lubchenco, E. Ostrom, Z. Ouyang, W. Provencher, C. L. Redman, S. H. Schneider, and W. W. Taylor. 2007. Complexity of coupled human and natural systems. Science 317:1513-1516. http://dx.doi.org/10.1126/ science. 1144004

Lujala, P. 2009. Deadly combat over natural resources: gems, petroleum, drugs, and the severity of armed civil conflict. Journal of Conflict Resolution 53:50-71. http://dx.doi.org/10.1177/00220$\underline{02708327644}$

Lujala, P. 2010. The spoils of nature: armed civil conflict and rebel access to natural resources. Journal of Peace Research 47:15-28. http://dx.doi.org/10.1177/0022343309350015

Martin, A., E. Rutagarama, A. Cascão, M. Gray, and V. Chhotray. 2011. Understanding the co-existence of conflict and cooperation: transboundary ecosystem management in the Virunga Massif. Journal of Peace Research 48:621-635. http://dx. doi.org/10.1177/0022343311412410

Masaba, S., and M. Odeng. 2016. Tanzanian pirates kill four Ugandan fishermen. New Vision 8 June. [online] URL: https:// www.newvision.co.ug/new vision/news/1426497/tanzanian-pirateskill-ugandan-fishermen

Matsuishi, T., L. Muhoozi, O. Mkumbo, Y. Budeba, M. Njiru, A. Asila, A. Othina, and I. G. Cowx. 2006. Are the exploitation pressures on the Nile perch fisheries resources of Lake Victoria a cause for concern? Fisheries Management and Ecology 13:53-71. http://dx.doi.org/10.1111/j.1365-2400.2006.00477.x

McClanahan, T., E. H. Allison, and J. E. Cinner. 2015. Managing fisheries for human and food security. Fish and Fisheries 16:78-103. http://dx.doi.org/10.1111/faf.12045

McConnell, W. J., J. D. A. Millington, N. J. Reo, M. Alberti, H. Asbjornsen, L. A. Baker, N. Brozović, L. E. Drinkwater, S. A. Drzyzga, J. Fragoso, D. S. Holland, C. A. Jantz, T. A. Kohler, H. D. G. Maschner, M. Monticino, G. Podestá, R. G. Pontius, C. L. Ledman, D. Sailor, G. Urquhart, and J. Liu. 2011. Research on coupled human and natural systems (CHANS): approach, challenges, and strategies. Bulletin of the Ecological Society of America 92:218-228. http://dx.doi.org/10.1890/0012-9623-92.2.218

Mitchell, S. M., and B. C. Prins. 1999. Beyond territorial contiguity: issues at stake in democratic militarized disputes. International Studies Quarterly 43:169-183. http://dx.doi. org/10.1111/0020-8833.00115

Mitchell, S. M., and C. G. Thies. 2012. Resource curse in reverse: how civil wars influence natural resource production. International Interactions 38:218-242. http://dx.doi. org/10.1080/03050629.2012.658326

Muawanah, U., R. S. Pomeroy, and C. Marlessy. 2012. Revisiting fish wars: conflict and collaboration over fisheries in Indonesia. Coastal Management 40:279-288. http://dx.doi.org/10.1080/089$\underline{20753.2012 .677633}$

Mulumba, D., and W. M. Olema. 2009. Policy analysis report: mapping migration in Uganda. IMMIS-African migration and gender in global context: implementing migration studies report. IMMIS, Kampala, Uganda. [online] URL: http://www. academia.edu/4485664/Mapping_Migration_in_Uganda

Murphy, M. N. 2007. The blue, green, and brown: insurgency and counter-insurgency on the water. Contemporary Security Policy 28:63-79. http://dx.doi.org/10.1080/13523260701240351

New Vision. 2014. Uganda, Kenya strike deal on Migingo. New Vision 21 July. [online] URL: https://www.newvision.co.ug/ new vision/news/1303406/uganda-kenya-strike-deal-migingo

Norwegian Refugee Council (NRC), and Internal Displacement Monitoring Centre (IDMC). 2012. Uganda: need to focus on returnees and remaining IDPs in transition to development. Norwegian Refugee Council, Geneva, Switzerland. [online] URL: http://www.internal-displacement.org/sites/default/files/ publications/documents/201205-af-uganda-overview-en.pdf

Norwegian Refugee Council (NRC), Internal Displacement Monitoring Centre (IDMC), and the United Nations Office for the Coordination of Humanitarian Affairs (UNOCHA). 2008. Guidance on profiling internally displaced persons. United Nations, Geneva, Switzerland. [online] URL: https://www.refworld.org/ docid/47b5ad3a2.html

Office of Disaster Management (Uganda). 2012. The 2010-2011 integrated rainfall variability impacts, needs assessment and drought risk management strategy. Office of the Prime Minister, Kampala, Uganda. [online] URL: http://gfdrr.org/sites/gfdrr/ files/UGANDA PDNA Report 2012.pdf 
Ogutu-Ohwayo, R. 1990. The decline of the native fishes of lakes Victoria and Kyoga (East Africa) and the impact of introduced species, especially the Nile perch, Lates niloticus, and the Nile tilapia, Oreochromis niloticus. Environmental Biology of Fishes 27:81-96. http://dx.doi.org/10.1007/BF00001938

Okumu, W. 2010 Resources and border disputes in eastern Africa. Journal of Eastern African Studies 4:279-297. http://dx.doi. org/10.1080/17531055.2010.487338

Ostrom, E. 2009. A general framework for analyzing sustainability of social-ecological systems. Science 325:419-422. http://dx.doi.org/10.1126/science.1172133

Otieno, K. 2009. Prime Minister Raila Odinga has ruled out military intervention to resolve the dispute over Migingo Island. Standard 26 April. [online] URL: https://www.standardmedia.co. ke/article/1144012547/raila-rules-out-military-intervention-in-migingo

Pauly, D., R. Hilborn, and T. A. Branch. 2013. Does catch reflect abundance? Nature 494:303-306. http://dx.doi.org/10.1038/494303a

Pingali, P., L. Alinovi, and J. Sutton. 2005. Food security in complex emergencies: enhancing food system resilience. Disasters 29:S5-S24. http://dx.doi.org/10.1111/j.0361-3666.2005.00282.x

Pomeroy, R., J. Parks, R. Pollnac, T. Campson, E. Genio, C. Marlessy, E. Holle, M. Pido, A. Nissapa, S. Boromthanarat, and N. Thu Hue. 2007. Fish wars: conflict and collaboration in fisheries management in Southeast Asia. Marine Policy 31:645-656. http://dx.doi.org/10.1016/j.marpol.2007.03.012

Pomeroy, R., J. Parks, K. L. Mrakovcich, and C. LaMonica. 2016. Drivers and impacts of fisheries scarcity, competition, and conflict on maritime security. Marine Policy 67:94-104. http://dx. doi.org/10.1016/j.marpol.2016.01.005

Ponte, S. 2005. Bans, tests, and alchemy: food safety standards and the Ugandan fish export industry. Danish Institute for International Studies Working Paper. No. 2005/19. Danish Institute for International Studies, Copenhagen, Denmark. [online] URL: https://www.files.ethz.ch/isn/18423/bans_tests_alchemy. pdf

Ross, M. L. 2004. How do natural resources influence civil war? Evidence from thirteen cases. International Organization 58:35-67. http://dx.doi.org/10.1017/S002081830458102X

Salehyan, I. 2010. The delegation of war to rebel organizations. Journal of Conflict Resolution 54:493-515. http://dx.doi. org/10.1177/0022002709357890

Salehyan, I., and K. S. Gleditsch. 2006. Refugees and the spread of civil war. International Organization 60:335-366. http://dx.doi. org/10.1017/S0020818306060103

Smith, T. G. 2014. Feeding unrest: disentangling the causal relationship between food price shocks and sociopolitical conflict in urban Africa. Journal of Peace Research 51:679-695. http://dx. doi.org/10.1177/0022343314543722

Sorens, J. 2011. Mineral production, territory, and ethnic rebellion: the role of rebel constituencies. Journal of Peace Research 48:571-585. http://dx.doi.org/10.1177/0022343311411743

Standard. 2009. MPs pass motion on UN intervention in Migingo dispute. Standard 28 May. [online] URL: https://www. standardmedia.co.ke/article/1144015304/mps-pass-motion-on-unintervention-in-migingo-dispute

Stewart, F., C. Huang, and M. Wang. 2001. Internal wars in developing countries: an empirical overview of economic and social consequences. Pages 67-103 in F. Stewart and V. Fitzgerald, editors .War and underdevelopment, Vol. 1. Oxford University Press, Oxford, UK. http://dx.doi.org/10.1093/acprof: oso/9780199241866.003.0004

Sundberg, R., and E. Melander. 2013. Introducing the UCDP georeferenced event dataset. Journal of Peace Research 50:523-532. http://dx.doi.org/10.1177/0022343313484347

Taabu-Munyaho, A. 2014. Anthropogenic and environmental impacts on the abundance and distribution of commercial fish stocks of Lake Victoria, East Africa. Dissertation. University of Iceland, Reykjavik, Iceland.

Taabu-Munyaho, A., R. J. Kayanda, I. Everson, T. B. Grabowski, and G. Marteinsdóttir. 2013. Distribution and exploitation of Nile perch Lates niloticus in relation to stratification in Lake Victoria, East Africa. Journal of Great Lakes Research. 39:466-475. http://dx.doi.org/10.1016/j.jglr.2013.06.009

Teh, L. C. L., and U. R. Sumaila. 2013. Contribution of marine fisheries to worldwide employment. Fish and Fisheries 14:77-88. http://dx.doi.org/10.1111/j.1467-2979.2011.00450.x

Ugandan Bureau of Statistics (UBOS). 2012. Uganda demographic and health survey 2011. Ugandan Bureau of Statistics, Kampala, Uganda. [online] URL: https://dhsprogram. com/pubs/pdf/FR264/FR264.pdf

United Nations. 1993. World economic survey 1993: current trends and policies in the world economy. United Nations, New York, New York, USA. [online] URL: https://www.un.org/ development/desa/dpad/wp-content/uploads/sites/45/PDFs/ WESS/1993wes.pdf

Uppsala Conflict Data Program (UCDP). UCDP conflict encyclopedia. Uppsala University, Uppsala, Sweden. [online] URL: https://ucdp.uu.se/\#/encyclopedia

Van der Knaap, M., D. Manara Kamitenga, L. Ngoie Many, A. Esube Tambwe, and G. J. De Graaf. 2014. Lake Tanganyika fisheries in post-conflict Democratic Republic of Congo. Aquatic Ecosystem Health and Management 17:34-40. http://dx.doi. org/10.1080/14634988.2014.882722

van Zwieten, P. A. M., J. Kolding, M. J. Plank, R. E. Hecky, T. B. Bridgeman, S. MacIntyre, O. Seehausen, and G. M. Silsbe. 2016. The Nile perch invasion in Lake Victoria: cause or consequence of the haplochromine biomass decline. Canadian Journal of Fisheries and Aquatic Sciences 73:622-643. http://dx.doi. org/10.1139/cjfas-2015-0130

Warner, M. 2000. Conflict management in community-based natural resource projects: experiences from Fiji and Papua New Guinea. ODI Working Paper no. 135. Overseas Development Institute, London, UK. [online] URL: https://www.odi.org/sites/ odi.org.uk/files/odi-assets/publications-opinion-files/2738.pdf

Wekesa, P. W. 2010. Old issues and new challenges: the Migingo Island controversy and the Kenya-Ugandan border. Journal of East African Studies 4:331-340. http://dx.doi.org/10.1080/17531$\underline{055.2010 .487343}$ 
Wood, R. M. 2010. Rebel capacity and strategic violence against civilians. Journal of Peace Research 47:601-614. http://dx.doi. org/10.1177/0022343310376473

Wood, R. M., and J. L. Thomas. 2017. Women on the frontline: rebel group ideology and women's participation in violent rebellion. Journal of Peace Research 54:31-46. http://dx.doi. org/10.1177/0022343316675025

World Bank. 2011. World development report 2011: conflict, security and development. World Bank, Washington, D.C., USA. [online] URL: https://siteresources.worldbank.org/INTWDRS/ Resources/WDR2011_Full_Text.pdf

World Bank. 2013. World development indicators. World Bank, Washington, D.C., USA. http://wdi.worldbank.org/tables

World Food Programme. 2017. Burundi. World Food Programme, Rome, Italy. [online] URL: http://www1.wfp.org/countries/ burundi 